\author{
G. A. Bazarbayeva, G. S. Jumabekova
}

\title{
ON THE STUDY OF THE SCENES OF TORMENT IN THE ART OF PEOPLE OF PAZYRYK CULTURE BASED ON MATERIALS FROM KURGAN 11 OF THE BEREL GRAVEYARD IN THE KAZAKH ALTAY
}

In this article we analyse the scene of mauling from the saddle cover found in mound $11\left(4^{\text {th }}-3^{\text {rd }} c . B C\right)$ of the Berel cemetery in the Kazakh Altay.

Keywords: Kazakh Altay, Early Iron Age, art.

Vyacheslav Murzin (1951-2019), a student of the outstanding $20^{\text {th }}$ century archaeologist Alexey I. Terenozhkin (1907-1981), made every possible attempt to maintain scientific contacts with members of Kazakh archaeology. In 2019, his latest article «Alexey Terenozhkin — the founder of the Kyiv school of Scythian studies» was published in Kazakhstan, in which V. Yu. Murzin pointed out that for the first time he had come across some materials on Kazakh archaeology in the library of A. I. Terenozhkin, and that "...Alexey I. cherished his friendship with his Kazakh colleagues, closely following their field discoveries and scientific developments. He insisted that I must do the same as well...» (Мурзин 2019, с. 45) ${ }^{1}$. Scientific connections of V. Yu. Murzin with Kazakhstan are clearly demonstrated by his involvement in research volumes (Мурзин 2013; 2019; Мурзин, Шлайфрер 2017). He invited colleagues from Kazakhstan to contribute to the almanac «History of Weapons", in which he was deputy editor-inchief. The highlights of V. Yu. Murzin's work are succinctly described in the memoirs of S. S. Bessonova and S. A. Skoriy (Бессонова, Скорый 2020), the Scythologists from the Institute of Archaeology of the National Academy of Sciences of Ukraine.

Introduction. In archaeology of the Early Iron Age of Eastern Eurasia, the results obtained from the study of the mounds with permafrost,

1. Here and further our translation - B. G., D. G.

(c) G. A. BAZARBAYEVA, G. S. JUMABEKOVA, 2021 known in Kazakhstan, Russia and Mongolia, are of specific importance. For the first time in the history of science, this type of sites was studied in the second half of the $19^{\text {th }} \mathrm{c}$. in the Berel steppe and in Katanda by V. V. Radlov, who was at the time a teacher in the Barnaul District School of Mines (Радлов 1989; Юсупов 2012).

In Kazakhstan, kurgans with permafrost were investigated in the Berel cemetery by the expedition of A. Kh. Margulan Institute of Archaeology led by Z. Samashev (Самашев 2011).

In this paper, we present the analysis of the scene from a saddle cover found in kurgan 11 of Berel $\left(4^{\text {th }}-3^{\text {rd }}\right.$ centuries BC). This material was first published in the Povolzhskaya Arkheologiya journal (Алтынбеков и др. 2019; Джумабекова, Базарбаева 2019). Here, we provide new data based on the analysis of the informative elements of the animal images and broaden the range of the analogies.

Characteristics and analysis of the material. The cemetery of Berel is located at the most easterly region of the Republic of Kazakhstan, where the four countries - Kazakhstan, Russia, Mongolia, and China - share the borders (fig. 1). Kurgan 11 (fig. 2) was investigated during the two field seasons in 1998-1999.

In kurgan $11(33.5 \times 22.8 \mathrm{~m}$ in diameter, just over $2 \mathrm{~m}$ in height), in a log coffin placed within a $\log$ cabin, a 30-40 year old man and a 5060 year old woman were buried, accompanied by 13 horses (Самашев 2011, с. 51, 56, 123) (fig. 3).

In 1999, the content of the burial chamber was extracted in blocks for further laboratory studies. After completion of the archaeological work, organic objects were stored in a freezer in the laboratory of $\mathrm{K}$. Altynbekov. By the diligent effort of the conservators, it was possible to recreate the 


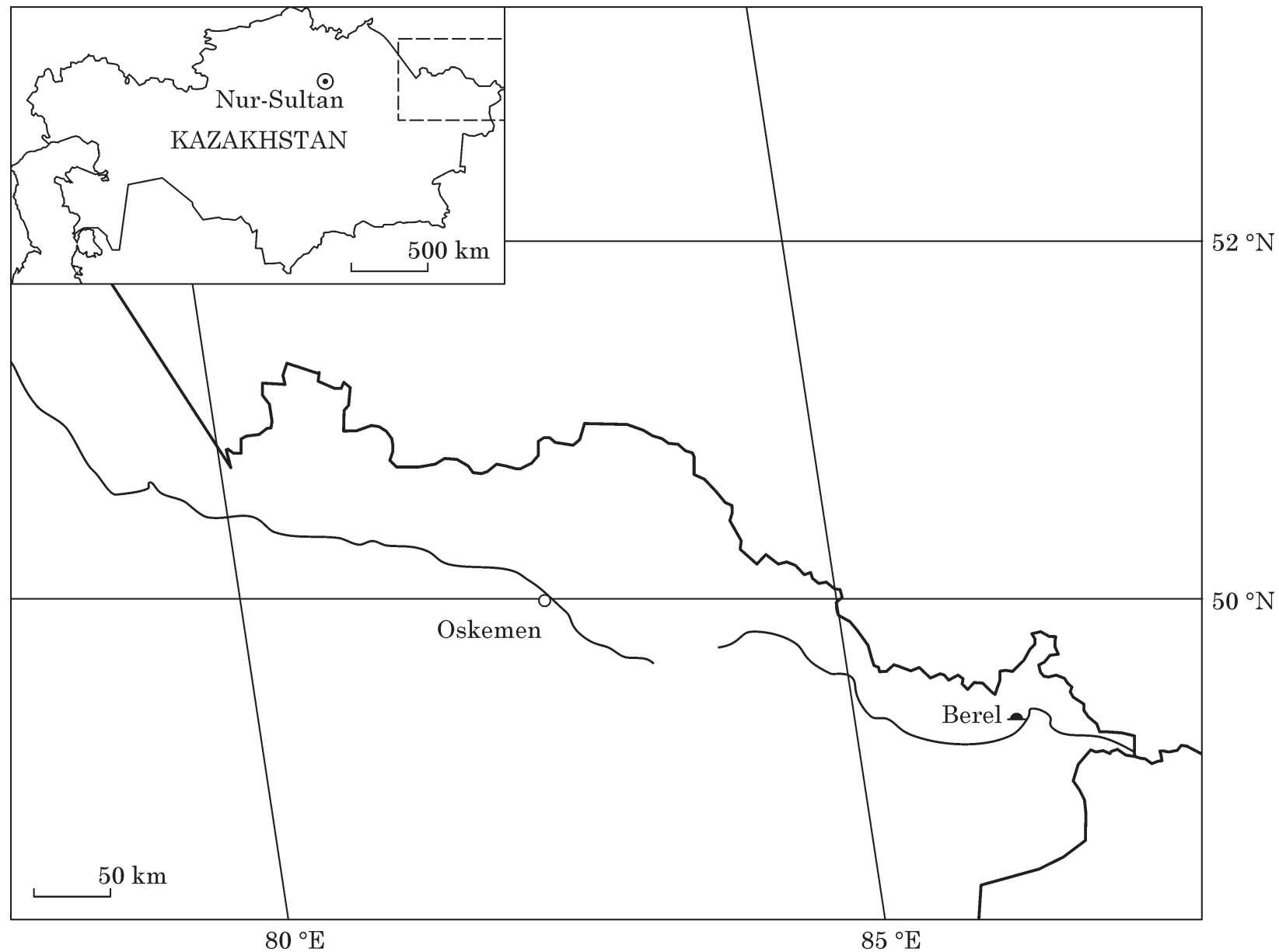

Fig. 1. Location of the Berel cemetery in Kazakhstan. The map was prepared by M. A. Antonov

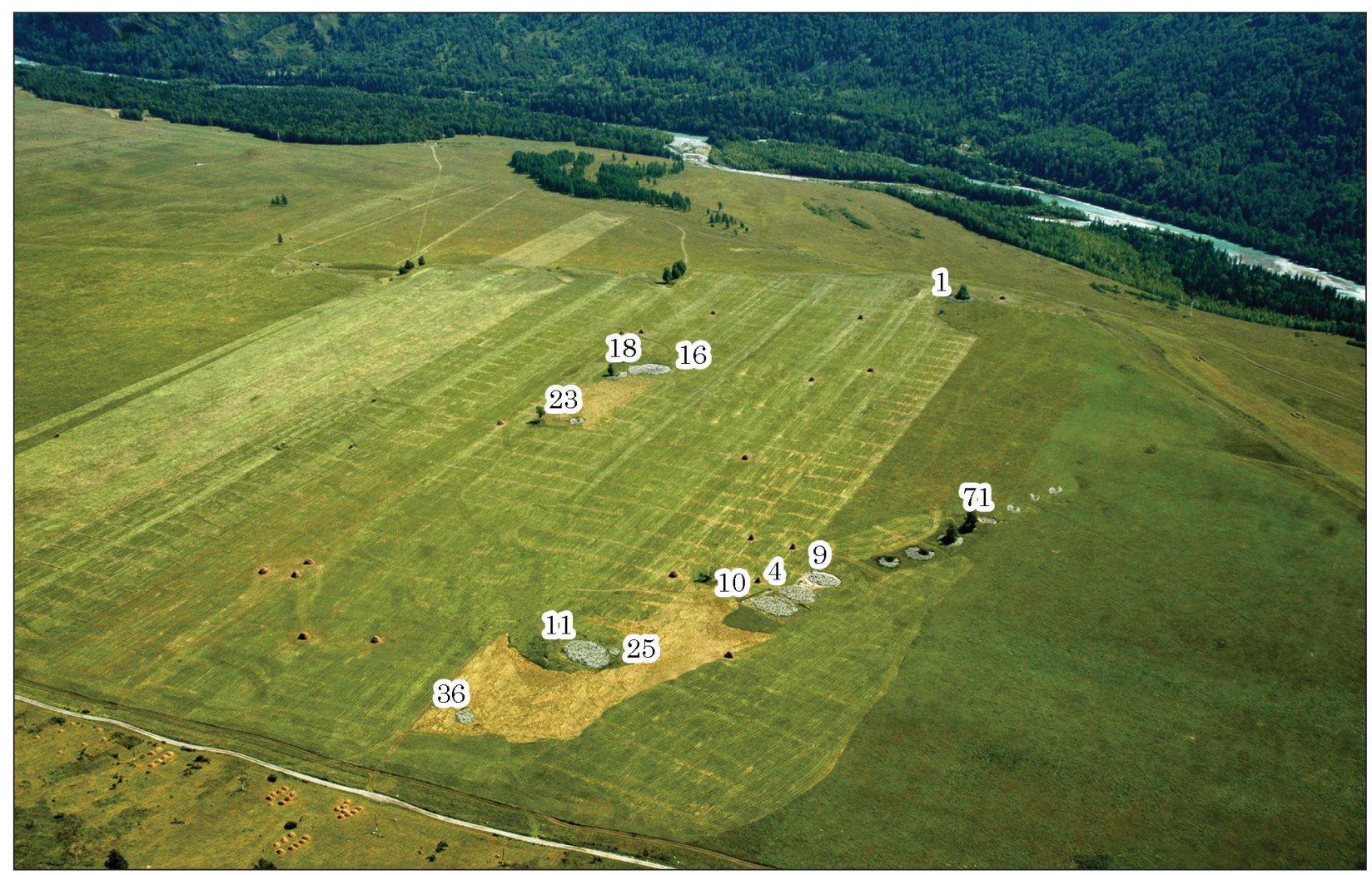

Fig. 2. The cemetery of Berel: an aerial view of the site (after Самашев 2011) 


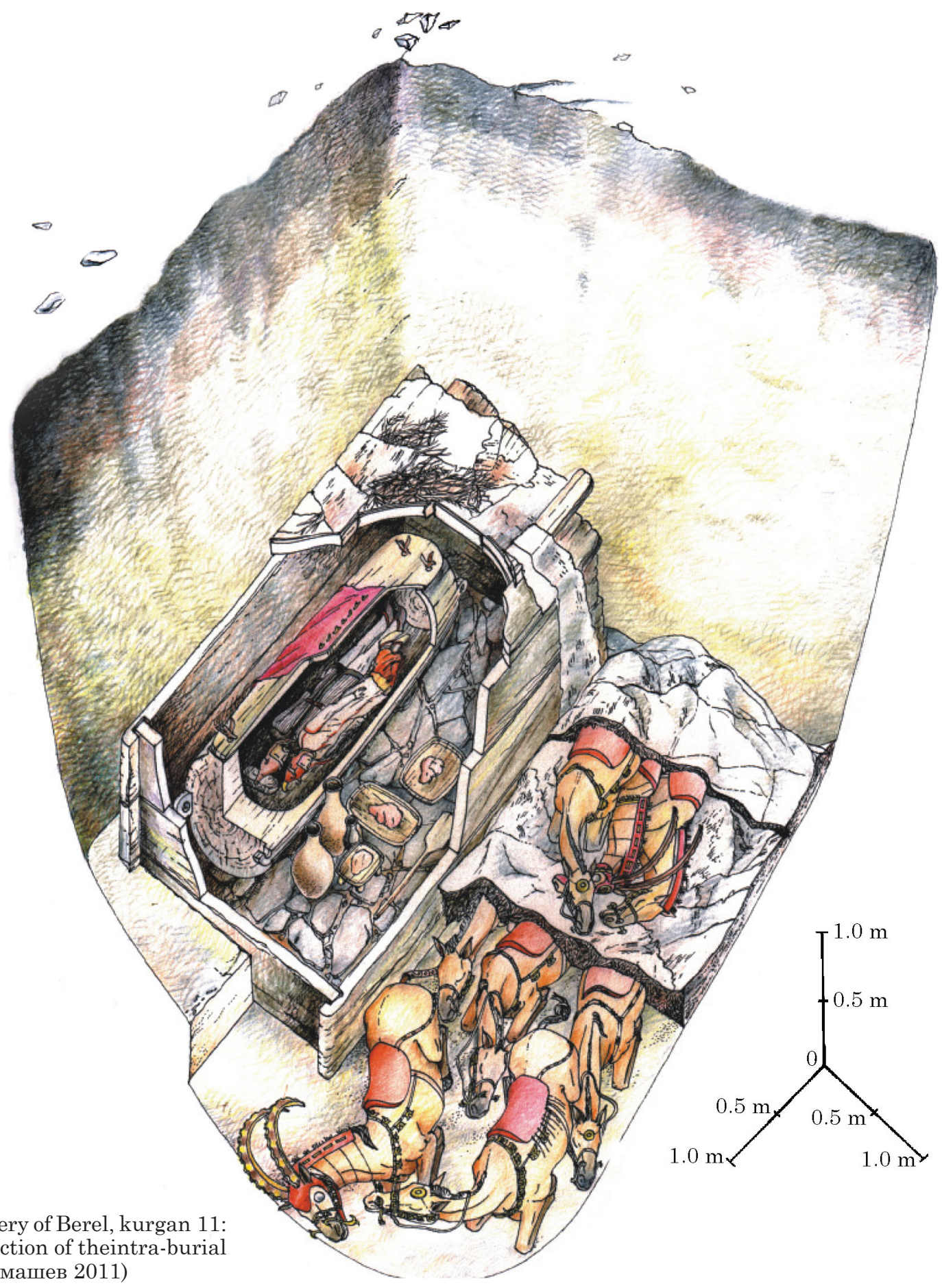

Fig. 3. The cemetery of Berel, kurgan 11: graphic reconstruction of theintra-burial complex (after Самашев 2011)

outstanding examples of the material culture of the Kazakh Altay (Алтынбеков 2014). This work continues to this day.

One of the striking works of ancient art, restored in the Scientific and restoration laboratory "Ostrov Krym» (led by K. Altynbekov), is the saddle cover, decorated with embroidery depicting a scene of mauling of an ungulate by four predators of different species (suborders) (fig. 4; Алтынбеков и др. 2019, с. 108-112, рис. 2; 6).

The technique of rendering of the animal hair is similar to that recorded, for example, on the saddles from the Berel mound 10 (Самашев
2011, pис. 29; 43), namely, highlighting parts or fragments of the image with colour-contrasting inserts. This technique was used on the saddle covers with images of eagle-griffins («roosters») and androcephals from Berel, as well as on other objects from the sites of the Pazyryk Culture (the images of a sphinx on the carpet from the Fifth Pazyryk kurgan, a moose on the saddle cover from the Second Pazyryk kurgan, etc.).

Based on the size of the horns and the number of semicircles on them, indicating the transverse ridges, as well as a thick thorax mane of the ungulate animal, it can be assumed that the saddle 


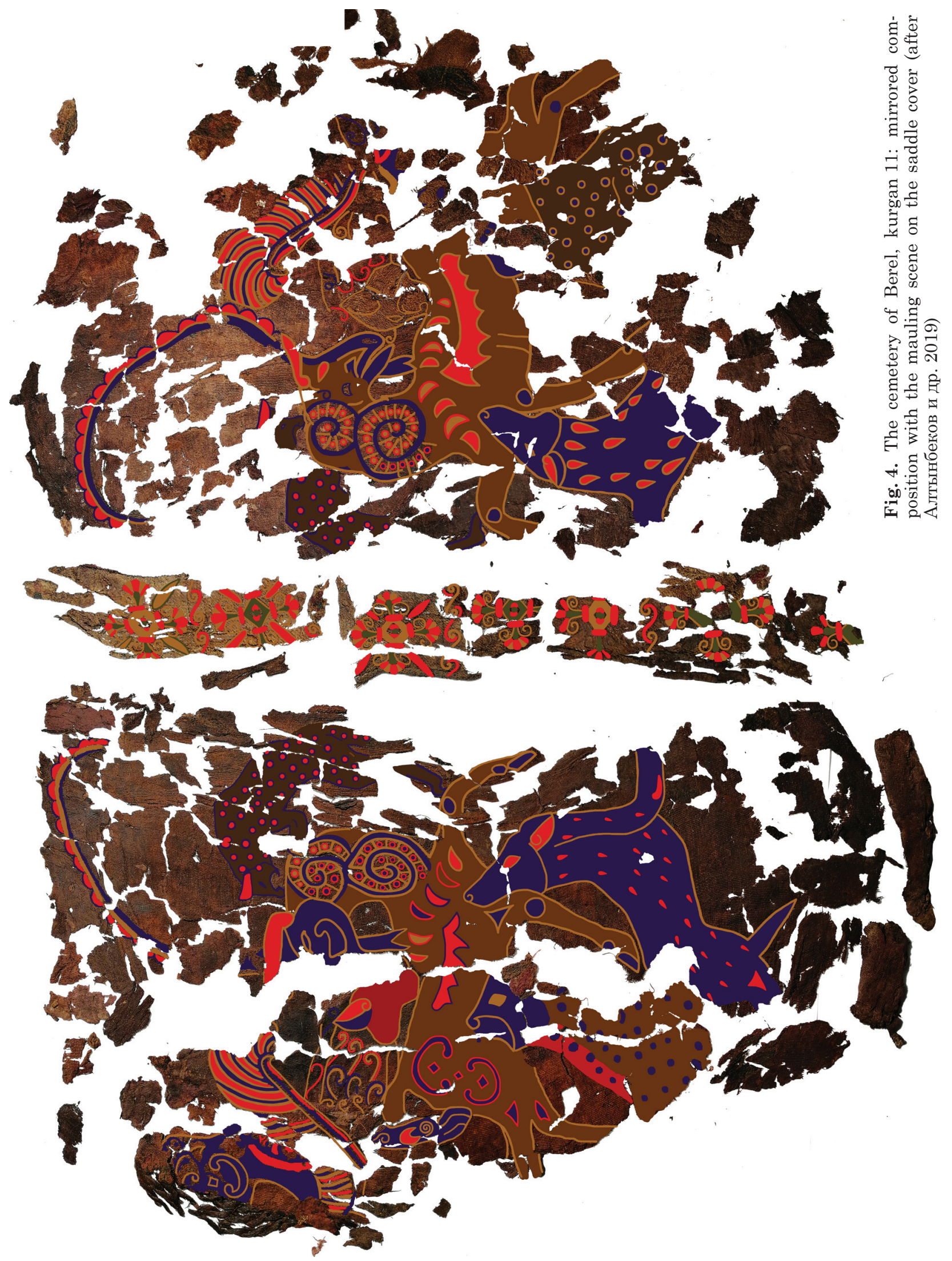


cover depicts adult sturdy mountain goats (Capra sibirica). Their main threat were snow leopards and wolves, which are shown in the discussed mauling scene.

However, some details of the image, artistic techniques of rendition of the patterns suggest that the central character of the mauling scene on the saddle is a horse disguised as a mountain goat. Horns, which are similar to those of the horses in masks from the Berel kurgans buried in mounds 10 and 11 , support this assumption.

Presentation of the horns of mountain goats as a row of semicircles has been known from a number of nomadic sites in the Central Asia - Alucheiden (Ordos), Dagan-Teli (Tuva), Aymyrlig 7 (Tuva), and others (Богданов 2006, табл. LXV: 3; LXIII: 3; LXXIV: 2). However, in those cases, depicted was obviously a goat rather than a disguised horse. It is worth noting that the horns in the image from Berel are as long as those sculpted on the masks of the co-buried horses in the Berel kurgans. However, horns of the ungulate animals depicted on the saddle cover are sharply bent. It is also possible that this technique was determined by the shape and size of the saddle cover on which the scene was placed.

In the analysed image of the ungulate, of particular interest are the swirls located on the animal's neck and divided into sectors Kurgan are also coiled in a spiral and divided into sectors (Руденко 1953, рис. 172, 178, 180). Similar, but not identical to that of Berel, division of the twisted horns into sectors, thus rendering a texture, was applied to the saddle pendant from the First Pazyryk Kurgan (Руденко 1953, табл. CXII). Similar elements in the form of a spiral are present in other images. For example, on the saddle pendants in the shape of a fish around the head of a ram from the Second Pazyryk Kurgan, the fish is partitioned into sectors along the spine, with gold circles inside (Руденко 1953, рис. 167). The tails of the fantastic beasts from the tattoos on the leg and back of a man from the Second Pazyryk.

Among the early Saka sites which contain objects decorated with images of animals with such elements as volutes and spirals, Arzhan $2\left(7^{\text {th }} \mathrm{c}\right.$. BC) can be mentioned. As such, the ornamentation of the handle and blade of the iron dagger with gold plates represents a combination of images of animals, wings, and spirals. As a whole, they form a distinctive decoration, an ornament. Among the animal images in the decoration of the dagger, tigers with characteristic stripes, imitating the colour pattern of the predator's hair, and stylised herbivores virtually composed of spiral swirls can be mentioned.

The iron knife from Arzhan 2 with a ring top with golden inserts features a handle decorated with an ornament of $\mathrm{V}$-shaped elongated curved figures (Čugunov et al. 2010, taf. 10: 1; 11: 1; 41: 1) composed of highly stylized images of rams and spirals. The handle decoration of the second knife with golden inserts is composed of several double (paired) spirals running clockwise (Čugunov et al. 2010, taf. 10: $2 ; 11: 2 ; 41: 2$ ).

In the mountains of the Chinese part of the Mongolian Altay and in the Helan Mountains $\left(9^{\text {th }}-8^{\text {th }}\right.$ c. BC), petroglyphs «in the deer stone style» have been discovered. Among them, there is an image of a horse with its thigh marked by a counter-clockwise spiral (Варенов, Черемисин 2018, puc. 3: 6, 7), as well as a drawing of a deer completed with two characteristic counter-clockwise spirals (Варенов 2018a, рис. 5: 6, 7; 2018b, рис. 2: 1). The image of a deer from the Halankou Pass is decorated with "tiger" stripes, the thigh and shoulder areas - with spirals, and a hump is indicated on the back. On the deer stones, deer torsoes apparently have never been decorated with spirals around hips and shoulders and / or with «tiger» stripes.

Images of tigers from Helan with their bodies decorated with stripes and spirals bear a close analogy to the predatory animals mauling an ungulate animal depicted on a bronze mirror from burial 1612 of the Guo State cemetery in Shangcunling (Варенов 2018a, рис. 8: 4; 2018b, рис. 1: 4). They are dated to the second half of the $9^{\text {th }}$ - first half of the $8^{\text {th }} \mathrm{c}$. BC, no later than 655 BC. Stylistic manner of ornamentation of the shoulder and / or thigh with spirals or circles was the preferred way of body decoration of predatory animals for the Nanshangen type bronzes (Варенов 2018b, с. 36).

The mirror from grave 1612 of Shangcunling, China (Богданов 2006, табл. LXXVI: 5), $9^{\text {th }}$ $8^{\text {th }}$ c. BC, is decorated with images of two predators of the Helan type, an ungulate animal, and a bird. The figures of the predators are filled with an ornament on the inside, including spiral counter-clockwise swirls, one located on the shoulder and another on the thigh. E. S. Bogdanov finds analogies to them in the Central Asia and in the nomadic world. They are considered to be at the bottom of the iconographic schemes adopted by the nomads, along with the mirror from the collection of the University of Tokyo (Богданов 2006, c. 84).

The belt buckle with an image of a "walking» wolf-like predator with counter-clockwise spirals placed on its thigh and shoulder is known among the finds from the Central Asian hinterlands, $5^{\text {th }}-4^{\text {th }}$ c. ВC (Богданов 2006, табл. XXXVII: 2). A predator with twisted torso from burial 30 of the Alagou cemetery (Xinjiang) has a spiral swirl (counter-clockwise) on its shoulder (Богданов 2006, табл. XXXIX: 3). A belt buckle with a mauling scene from the Ningxia Region, Hong Kong, contains an image of a feline predator with spiralshaped counter-clockwise swirls around its neck, shoulder (perhaps to mark the mane) and thigh, $4^{\text {th }}-3^{\text {rd }}$ c. ВC (Богданов 2006, табл. XLIX: 3). In the $4^{\text {th }}$ c. BC Ningxia burial complexes, paired 
belt plates are recorded with a mirrored image of mauling scenes and a "walking» predator. In the majority of these "wolf-like predators, the entire surface of the body is covered with spiral-, drop-or leaf-shaped dashed ornament» (Богданов 2006, c. 63).

In the tiger drawings from Daxifenggou (Daxifogou) in Helan County of the Ningxia Region, spirals on shoulders and thighs of the tigers are pointing in different directions; these images correlate with that of a deer from the Halankou (Helan Mountains) Pass (Варенов 2018b, рис. 1: 1, 2).

On the Beya stela (Middle Yenisey), the $1^{\text {st }}$ mil. $\mathrm{BC}$ images of deer are covered with multi-directional spiral swirls all over their bodies. In particular, the upper ungulate animal is decorated with counter-clockwise swirls on its thigh and shoulder. It has been suggested that a cosmogony myth is embodied on this stela (Дэвлет, Дэвлет 2011, с. 240 ; рис. 3 : 14).

Ornamentation of animal images (volutes and spiral swirls) is characteristic for the art monuments of different regions of the Steppe in the Scythian time. Specifically, one of the compositions in the petroglyphs of Tepsey shows a bull (?) and a goat with their torsoes decorated with swirls, as well as anthropomorphic figures and a bird. E. M. Miklashevich refers to them as outstanding examples of the decorative style of the Tagar Culture (Миклашевич 2007, с. 24; рис. 11). On the torso of the bull, two counter-clockwise swirls are traditionally shown - on its shoulder and thigh, respectively. The goat has four swirls on the body from its neck to thigh, also running counter-clockwise. In the petroglyphs of AldyMozaga Mountain, which are dated to the period from the Bronze Age to the $1^{\text {st }}$ mil. $\mathrm{AD}$, among the animal figures - elk, deer, ram, boar, bird, fish, etc., - a three-pointed socket is incused in the shape of spiral clockwise swirls (Миклашевич 2007 , с. 28 ; рис. 14 ).

Torcs with the ends in the shape of fantastic feline predators from kurgan 2 of the Ulandryk IV cemetery have two swirls pointing in different directions on the neck and shoulder, possibly imitating their coat, $4^{\text {th }}-3^{\text {rd }} c$. ВC (Кубарев 1987, рис. $46: 2$; с. 118).

The image of ungulates on the log-sarcophagus from kurgan 2 of the Bashadar cemetery $\left(6^{\text {th }} c\right.$. BC) shows clockwise swirls on the thigh and shoulder, as well as on the neck, of the animal, apparently, imitating the coat and hair on the bottom side of the neck (Руденко 1960, рис. 21; табл. XXX; XXXI). The image of a saiga, whose shoulder and thigh are filled with volutes pointing in different directions, decorates the arc of the saddle pommel, the Uvarov's collection, Altay (Королькова 2006, табл. 13: 7). Carving of a deer on the log from kurgan 2 of the Tuekta cemetery $\left(6^{\text {th }} \mathrm{c}\right.$. BC) has two large counter-clockwise swirls on the thigh and shoulder of the animal
(Руденко 1960, рис. 154: ж; Королькова 2006, табл. 2: 5).

The figure of an ungulate animal, representing a fragment of the headdress, from the Pazyryk Culture kurgan 4 of Tashanta II, is decorated with clockwise spirals on the thigh and shoulder (Кубарев 1987, табл. XCVI: 9).

Thus, for a long time - from the early Scythian to Pazyryk, and across the vast area occupied by various archaeological cultures of the Early Iron Age, swirls and spirals were used in the decoration of different surfaces, including rock images, to schematically define / substantiate zoomorphic images. This aspect was analysed in detail by O. S. Sovetova in the context of the study of socalled "Altay" style, and the "survivance» of spirals and swirls to the Tagar-Tashtyk stage was noted (Советова 2017, с. 143).

Colour marking of the head or significant details of the fantastic beast, as seen in the animal images on the saddle cover from kurgan 11 of the Berel cemetery, is probably characteristic of the Pazyryk Culture sites. In particular, it was used in tattooing (Баркова, Панкова 2005).

On the left shoulder of the woman from Pazyryk kurgan 2, $300 \mathrm{BC}$, there is an image of a fantastic beast with the body of an ungulate and head of a predatory bird. The creature is drawn having large blackened horns; one of the horns has prongs in the form of bird heads, while the bases of the horns are similar to the one of the analysed image, i. e., with semicircles. The legs are blackened. On the chest of this fantastic beast there are blackened curved figures that bear analogies to the decoration of the tattoos on other Pazyryk mummies. The figure of an argali with twisted torso on the humeral part of the woman's right arm is shown with a sharply bent horn with annual rings and thick hair on the chest, the rear limbs blackened and covered with a curvilinear pattern (Баркова, Панкова 2005, рис. 2: 2). The tattooed drawings found on the mummy of the woman from Pazyryk (kurgan 2) are close to the images on other mummies from the same complex and from the Ukok mounds, $4^{\text {th }}-3^{\text {rd }} \mathrm{c} . \mathrm{BC}$ (Баркова, Панкова 2005, с. 50).

A tattoo is also known from a man from the Pazyryk kurgan 5, $250 \mathrm{BC}$, in the shape of feline predator, with the front part of its figure covered with blackened patterns forming spirals and curvilinear triangles (Баркова, Панкова 2005, c. 51-52). A thick scruff is also emphasised. On the humeral part of the man's right arm there is an image of a horse with twisted torso turned out and the rear limbs thrown up; its thigh and neck, legs and mane are filled with blackened curved figures (Баркова, Панкова 2005, рис. 5). On the right forearm of the person, an onager, or a horse, and a predator with striped coiled tail are depicted (Баркова, Панкова 2005, рис. 6). The horse has a swirl on its neck. On the right leg of the man, there are imag- 
es of two ungulates (Баркова, Панкова 2005, рис. 10) with blackened heads, horns and necks; their shoulders and thighs are decorated with swirls.

Images of animals on the mummy of a man from kurgan 5 of Pazyryk are close to the tattoos of the mummies from the burials of Ukok and kurgan 2 of Pazyryk. They feature characteristic «filling of the front part of their figures with curvilinear patterns and decorative design of images with spirals and triangles». There are similarities in the scenes as well. Yet, in the drawings on the body of the man from kurgan 5 of Pazyryk, there are no specific fantastic characters typical for the tattoos of the buried individuals in the Second Pazyryk, Ak-Alakha and Verkh-Kaljin kurgans (Баркова, Панкова 2005, с. 54).

A complex composition with several figures is unfurled on the right hand of the woman from kurgan 5 of Pazyryk: two tigers and a leopard attacking a deer and an elk (Баркова, Панкова 2005, рис. 14). The plot is close to that from the saddle cover from kurgan 11 of Berel. But in the latter case, all animals are shown in profile, whereas here the two predators are depicted as viewed from above on the front half of their torsos ("the rear part is shown in profile, the front one - en face, and the head - as if looking from above»). The body of one of the predators is covered with dark spots, with "particularly emphasised spine». If we consider separately the right and the left halves of the saddle, then, same as in the case of the woman from kurgan 5 of Pazyryk, each complex multi-figure composition appears to be self-contained (Баркова, Панкова 2005, c. $56-57)$.

N. V. Polosmak noticed that the tattoos on the bodies of the Pazyryk mummies show some similar images (the man from the Second Pazyryk kurgan, the woman from mound 1 of the AkAlakha 3 burial ground, the man from mound 3 of the Verkh-Kaljin II cemetery). "Fantastic and real animals, and fishes depicted on the bodies of the Pazyryk people represent a figurative language of the Pazyryk Culture, its writing, as well as the language of their ancestors» (Полосьмак 2000 , c. 99). This sacred writing was intended to convey information, probably of a mythological nature.

The purpose of the blackening of certain parts of the animal images was possibly to highlight, to emphasize the highlighted elements. In the images of predators, that would be powerful paws with claws, a long tail, jaws; in polymorphic creatures - fast legs, as well as obviously contradicting or not characteristic for ungulates (forming the base of the image, such as horses, goats) head with a beak, horns, wings, mane. They appear as if attached separately, not being inherent to the depicted creatures. This possibly points to essential features and those acquired, provided, complementing the new fantastic guise.
The felt applique on the saddle cover from kurgan 2 of Pazyryk with the image of a griffin - a fantastic creature - also contains colour marked beaked snout, neck, and front limbs (Руденко 1953, табл. CIX: 2; Полосьмак, Баркова 2005, рис. 3.12). Specifically marked are the wing (feathering of the lower edge), head, and left limbs of the fantastic predator in scenes of mauling of a mountain goat - decoration of the saddle coverings from the First Pazyryk kurgan (Руденко 1953, табл. CX: 1; CXI) and others. On the felt covering of the saddle from the First Pazyryk kurgan, $300 \mathrm{BC}$, one of the images of the goat features horns and almost the entire head highlighted with blue felt, the second one - only horns; griffins have highlighted ears, wings, and heads (or parts of the heads) (Полосьмак, Баркова 2005, рис. 3.5). It should be mentioned that the ungulates in the mauling scenes from Pazyryk are shown in a slightly different position - their legs are bent-weak under the weight of the attacking predator, and the leg is not extended forward as in the image we analyse here.

The horns of the argali, bent in a spiral, as on the saddle cover from kurgan 11 of the Berel cemetery, are known from the rock paintings of the Bronze Age and early nomads, for example, in Bayanjurek (southeast Kazakhstan) (Самашев 2012, рис. 25, 98, 107). Among the petroglyphs, the image of a lying mountain goat in cluster II (Shu-Ile interfluve) can be mentioned, whose horns are shown by semicircles, as in the scene on the saddle cover of the Berel kurgan 11; also, the image of a predator with spiral clockwise swirls on the shoulder and thigh, shown standing, with clawed paws and a long tail (Рогожинский 2016, рис. 295: 4, 7). A. E. Rogozhinskiy refers to the style, which depicts the characters of the petroglyphs, as an applique style (Рогожинский 2016, c. 542) and relates the emergence of the Late Saka sanctuary in the centre of the Shu-Ile interfluve with the migration of some nomadic groups into the region from the areas of the Pazyryk and Sagly Cultures of the Altay-Sayan region, and probably from the north-western regions of China not later than in the second half of the $3^{\text {rd }} \mathrm{c}$. BC (Рогожинский 2016, с. 548).

One can cite a number of scenes and images of the Jetysu petroglyphs (South-Eastern Kazakhstan), where artistic techniques show analogies with the characters from Berel. Specifically, the scenes where the goat is shown with high horns with emphasised ridges, known from Eshkiolmes, spirals are shown on the thigh and shoulder of the goat in the hunting scene in Maly Koitas; the image of a lying female deer also has two counter-clockwise spirals (Maymak); there is a scene in Eshkiolmes with a wolf chasing a mountain goat whose horns are depicted in the same way as in the analysed object from Berel (Бейсенов, Марьяшев 2014, фрото 20; 38; 89a; рис. 60). 
Correspondence with the stylistic elements of ungulate animals have been revealed in the animal style art of the Pazyryk Culture - in wood, leather, and felt. Objects of ornamental art from the elite mounds and ordinary burials of the $\mathrm{Al}$ tay Mountains - Tuekta, kurgan 1; Bashadar, kurgan 2; Ak-Alakha 1, 3; Tashanta I and others - demonstrate the closest match in the style and iconography to the petroglyphs and characters of the Pazyryk Culture. Meanwhile, a rather diverse range of zoomorphic characters from the Berel mounds shows just minimal resemblance in their style and repertoire with the petroglyphs (Рогожинский 2016, с. 544).

In the Kazakhstan, among the characters of the Bronze and Early Iron Age petroglyphs, images of animals with spirals on their torsoes are known: on the thigh and shoulder of the deer in sacrificial pose the symbols are shown pointing in different directions (Maymak) (Бейсенов, Марьяшев 2014, рис. 10); the spiral on the thigh of the goat is directed counter-clockwise (Eshkiolmes) (Бейсенов, Марьяшев 2014, рис. 21); on the thigh and shoulder of the goat one spiral is pointing clockwise and another counter-clockwise (Aksu-Jabagyly - Бейсенов, Марьяшев 2014, рис. 27). Images of ungulates - mountain goats and argali with volutes not only on thigh and shoulder, but all over the torso are present in Aksu-Jabagyly, Cholpon-ata, Eshkiolmes, Ust-Tuba (South Siberia) (Бейсенов, Марьяшев 2014, табл. XIV).

Images of spirals around the goat's neck from the described scene on the saddle resemble the twisted horns of the argali in the petroglyphs, for example, in the hunting scene from Eshkiolmes, where depicted are a deer, an argali, goats, and an archer (Бейсенов, Марьяшев 2014, рис. 8). The same way horns are shown in the scene with argali (with a picture of a deer and an unfinished image of an archer below) (Eshkiolmes); in the dog-hunting scene (Tekturmas); in the image of eagles and argali (Eshkiolmes), and others (Бейсенов, Марьяшев 2014, рис. $17 ; 32 ; 65)$. A particular resemblance to the horns is apparent from the division of these figures on the goats' necks into sectors. The connection of the meaning of a spiral with the image of the horns is indicated by the presence of the image of ram's head in profile on shoulder and thigh of the ungulate animals of other species (Королькова 2006, табл. 14: 18, 19); it is also known from the Pazyrykperiod materials of the Berel mounds (Самашев 2011, pис. 323), kurgan 21 of Yustyd 12, and kurgan 4 of Ulandryk III (Королькова 2006, табл. 14: 18, 19). Perhaps it shows a combination in one creature of images of three herbivores - a horse, a goat and a sheep, amalgamation of the characteristic techniques of Pazyryk - dressing up a horse and placing the head of an argali on the torso of another herbivore.

Regarding the representation of predators, it can be noted that the wolf on the saddle cover from Berel features the same technique as that of the image of the elk on the saddle cover from the Second Pazyryk kurgan, decorated with dropshaped inserts, expressing longer hair on the withers and neck (Руденко 1953, табл. CIX: 1). This technique is known from the art of Central Asia from the $4^{\text {th }} \mathrm{c}$. BC onwards. E. S. Bogdanov notes that the surface of the body of the majority of the wolf-like predators was covered with spiral, drop-, or leaf-shaped ornament (Богданов 2006, c. 63; табл. XLIX). Furthermore, the artistic rendering of the thigh in the form of thin "staples" or «horseshoe» with end bulging is suggested by the image of the elk in the scene of mauling by an eagle griffin on the saddle cover from the First Pazyryk kurgan (Полосьмак, Баркова 2005, рис. 3.6a), and by the image of a feline predator with the head of an argali in its jaws from the Central Asian - Ordos regions (Богданов 2006, табл. XLVI: 3). Felt saddle pendants in the shape of a wolf (Bashadar, kurgan 2) are decorated with spiral swirls on the nape, shoulders and thighs; claws are also shown (Богданов 2006, табл. CXXI: $1,2)$. The ears are set back to the head closer than on the saddle cover from Berel.

At the same time, the stylistic features of the wolf on the Berel saddle cover are distinctively different from the usual, canonical images of wolf on the objects from Pazyryk and the Siberian collection of Peter the Great, as well as from Jetysu. The latter style is characterized by specifically marked nose (upturned), snarling muzzle with marked teeth (Руденко 1960, рис. 143; 1962 , с. $31-32$; рис. $35-37$ ). Features of a wolf of the Scythian time in Altay have been defined by V. D. Kubarev, including a large head with long jaws, snarling muzzle, upturned wrinkled upper lips, elongated ears, rounded at the base and pointy at the ends, as well as with a swirl at the base of the ear, and a straight tail (Кубарев 1987, c. 119). From the described saddle cover from Berel, a more naturalistic representation of the wolf appearance is seen. According to specialists, predators with the particular layout of the ears and nose denote fantastic beasts associated with the otherworld (Королькова 2015, c. 176).

Among the materials from the monuments in Kazakhstan, in particular, from the Jetysu, certain similarities to the image of the lion - the rendition of the mane - can be found on the Berkkara buckle, $4^{\text {th }}-3^{\text {rd }}$ c. BC (Berkkara burial ground, Jambyl region) (Бернштам 1947, рис. 5: 6). It represents an object bearing the image of a lion with the open mouth, curled-back upper lip, «the eyeball strongly projecting forward», the eye with a high eyelid, the leaf-shaped ear set back to the head. The mane of the predator is shown in the form of three prominent strands, curled at the ends. The clasper is made in the form of the head and neck of a bird. A. N. Bernstam believed that it carries elements of schematisation in the draw- 
ing of the mane, incompleteness in the image as a whole (Бернштам 1947, c. 10).

Therefore, the scene on the saddle cover represents a dressed horse mauled by predators.

It has been shown that the images of horned horses, a horse-goat convey mythological ideas, widespread amongst the nomads of Eurasia and their neighbours. Myths featuring a horned horse in the $1^{\text {st }}$ mil. $\mathrm{BC}$ were especially common, «the role of the warrior-chief-hero was of a particular importance» at this time (Мец 2013, c. 101).

When analysing the worldview ideas of the Pazyryk communities, A. S. Surazakov came to conclusion that in the culture of the early nomads of Altay horse represented the solar cycle, and mountain goat was also of solar nature. According to the researcher, the elite of the Pazyryk society were transmitted to heavens (Суразаков 2011, c. 262, 264-265). We hold on to the assumption that the mythical creatures helped the elite reach the heavens.

A certain semantic meaning of the horse-goatdeer images was formed by the early Saka period. For example, the deer stones show images of herbivores (a deer with elongated and bent legs and a deer with beak-shaped snouts; goats, horses, sheep) and predators, forming a single composition. M. E. Kilunovskaya and V. A. Semenov concluded that horse, goat, sheep and deer are interchangeable animals, and that they symbolise the sacrifice. The deer with beak-shaped snouts help «bring prayers and sacrifices to the deity» and "transfer the souls of the dead to the otherworld». They appear as fantastic «bird-deer-horse» creatures. Predators are the tool of the sacrifice (Килуновская, Семенов 1999). Functional purpose of the deer stones, installed over the area of the mounds, is the transfer of the ritual-regulated values and sacrifices (Савинов 1994, с. 147). Based on the transformation of the horse from kurgan 36 of Berel with images of elk-griffin, as well as mauling scenes with the participation of elk, elk can also possibly be attributed to this range of sacrificial herbivores.

Apparently, the role of the victim of the polymorphic animal on the saddle cover from the Berel kurgan is also emphasized by the spiral-shaped figures on its neck described above. Apart from the role of transformation of the original appearance of the horse, masking the mane, they might have had a different meaning. The use of spiralshaped figures, swirls, and concentric circles in the images of the animals could "mark sacrificial or consecrated real animals» (Дэвлет 2017, c. 204).

E. F. Korolkova names several techniques to create a fantastic beast: a change of the natural colour; anatomical dysmorphology; and juncture of parts of different animals (Королькова 2015, c. 185). In our case, these may include unusual colouring of the predators (the wolf and lion with red wings), wings of the lions and, of course, the ibex with wings. Duplication - the mauling scene and fantastic beasts - indicates connection of the composition to the otherworld, death as a rebirth to life. "All hybrid monsters of the animal style of the early Eurasian nomads are creatures belonging to the otherworld» (Королькова 2015, c. 186).

These include cauldrons with rims decorated with winged horse-goats (Джумабекова, Базарбаева 2019, рис. 4: 2) and with legs in the form of argali (fig. 5: 1), in the form of a griffin swallowing the leg of an ungulate animal (fig. 5: 2 ), with the image of an antelope on the walls and a predator on the edge of the cauldron (fig. 5: 3). In such large vessels, meat of sacrificial animals was cooked. According to the tradition, libation of liquids from a zoomorphic vessel equalled to sacrifice. In the Hittite rituals, if the verb «drink» was followed by the verb "to make a sacrifice», the text reads as «drinking» the god, «to libate» or the king was «watering god» (Ардзинба 1982, с. 63$64)$. The vessel with zoomorphic design is related to the sacrificial animal; in a wider sense - to the victim.

Cauldrons from Jetysu and Kyrgyzstan, whose legs are designed in the form of limbs of herbivores (fig. 5: 4), probably imply that the vessel body, in which the sacrificial (?) animal was cooked, was associated with this animal. The same can be said about the cauldron (fig. 5: 3), whose walls are decorated with the image of antelope (fig. 5: 3b), while the figure of a predator (fig. 5: 3a) stands on the edge of the rim - in this case, the cauldron with such decoration can be considered as an expression of sacrifice, same as the similar scenes on other objects. The leg of the cauldron in the form of a foot of an herbivore, being swallowed by a fantastic predator (fig. 5: 2), quite transparently tells us about the symbolism of the cauldron in the culture of the nomads, and the scene of mauling in particular. The rim of the cauldron with protomas of winged mountain goats completes this series of symbolic objects. A. K. Akishev (Акишев 1984) once spoke exhaustively about the sacred person from the Issyk mound, whose kulakh* (*headdress) was decorated with images of winged and horned horses.

Headdresses decorated with images of polymorphic creatures is a characteristic feature of the Pazyryk Culture. The headdresses of the men buried in kurgans of the Ukok Plateau demonstrate the main characters of the bestiary of the Pazyryk people - the bird, deer, and horse with ibex horns (Полосьмак 2001, с. 65). Typically, Pazyryk male helmets were decorated with wooden figures of animals - horses and deer with ibex horns (Полосьмак 2001, c. 158). Thus, figurines of horses on the headdresses had attached horns of a mountain goat, the three-dimensional figurines in the kurgans of Ulandryk combined features of a horse and a sheep. The figurines of sheep had long limbs of a horse or a deer. This 

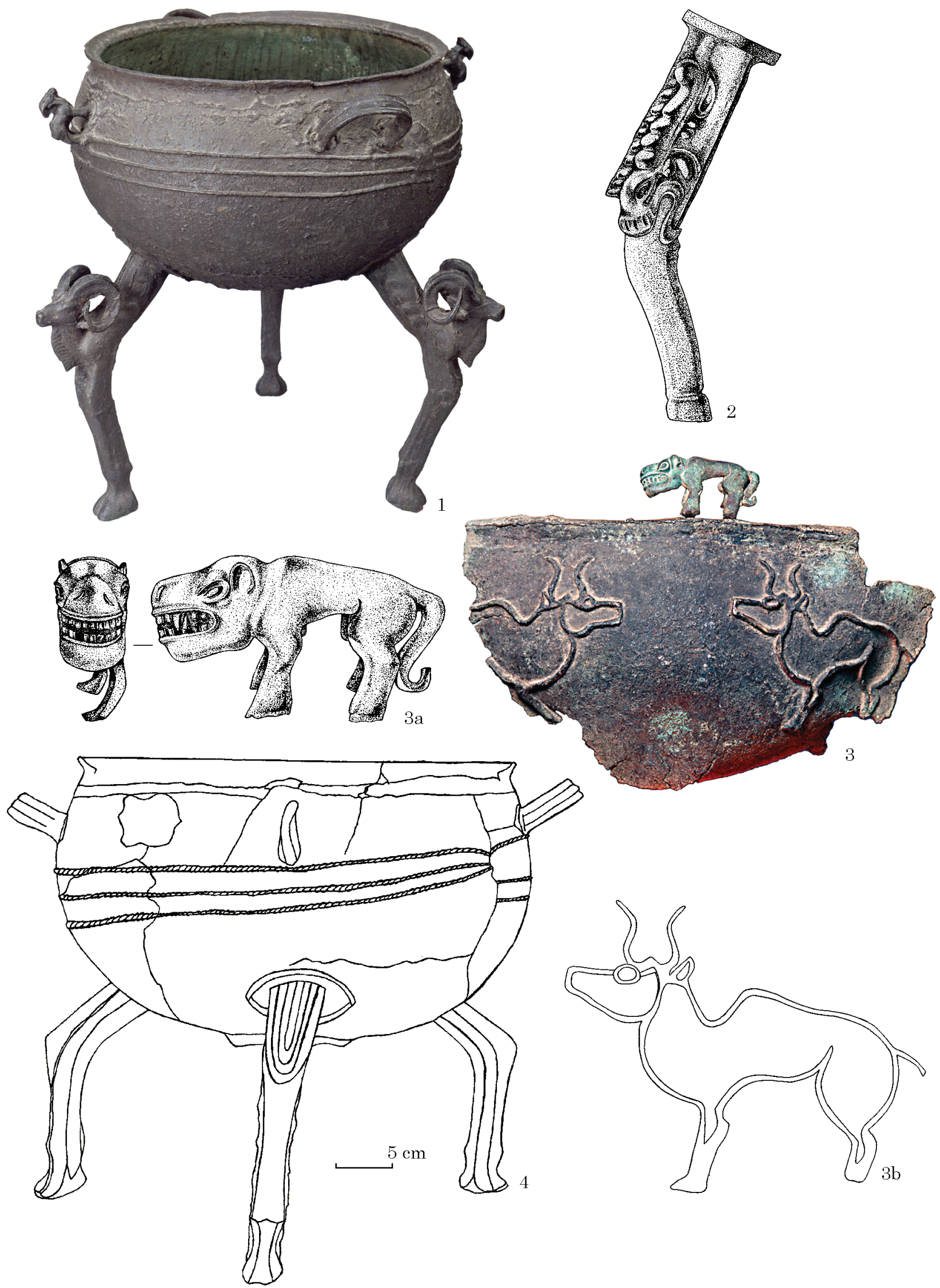

Fig. 5. Metal cauldrons with zoomorphic decoration. Suburbs of Almaty (Kazakhstan). Incidental finds: $1-1893$, the State Hermitage Museum, КП № 1654/1; 2 - decoration of the cauldron leg, the Central State Museum of the Republic of Kazakhstan, КП № 2280; 3 - a fragment of a cauldron, 1948, collections of the Central State Museum of the Republic of Kazakhstan; 4 - 1962, reposited in the Museum of Archaeology of the A. Kh. Margulan Institute of Archaeology ( $1-3-$ no scale) 
design of the headdress corresponds to the ritual transformation of the sacrificial horses, driven by the sacred meaning of wild animals (Черемисин 2008 , c. 75$)$.

One can also mention the torc from kurgan 1 of the Ak-Alakha 1 cemetery, where represented are two predators mauling an herbivorous animal positioned between them, and the head of a predator is also placed in the centre of the composition below (but in this case the same-species predators are shown); the insert on a quiver from kurgan 1 of Ak-Alakha 1, 308 BC, showing feline predators and wild boars, etc. (Богданов 2006, табл. LVI: 2; LVII: 2).

Scenes of predators attacking ungulates or mauling were a symbolic depiction of death and subsequent rebirth (Полидович 2006, с. 371). The rites of the so-called transitional type, the Jetysu ritual objects, decorated with images of animals, including winged horses-goats, are associated with the idea of life and death.

Concerning the connection of the arts of the inhabitants of the Altay with Western Asia, S. I. Rudenko noted: «In the arts of the Altay of the later periods $\left(5^{\text {th }} c\right.$. BC), connection with the arts of Western Asia is clearly shown in the images of animals» (Руденко 1968, с. 110). Essentially, the lion clutched at the back of the bull turning backwards with both its front limbs raised up is characteristic of the relief from Persepolis.

Amongst the body of Achaemenidian Persian motifs, wings bent forward can also be mentioned, which are clearly seen on the saddle cover from Berel (Артамонов 1973, с. 222-226), as well as extended forward leg of the herbivore and turned back head of the ungulate animal. "Some have wings similar in shape to one of the Assyrian griffins, while others have the ends of the wing feathers directed forward, which was typical for Persian images» (Руденко 1961, с. 49).

Conclusions. In science, mounds with permafrost have been known for more than 150 years. During this time, the number of sources has grown significantly. However, owing to the restorers, archaeologists have obtained fundamentally new data on the culture of the Early Iron Age population of the east of Eurasia, in particular, the Kazakh Altay.

Scenes of mauling, known in various media, such as metal, wood, bone, leather, tattoos, rock surfaces, and found in archaeological sites throughout the steppe belt of Eurasia, reflect the eternal principle of the struggle of opposites, symbolise the idea of rebirth through destruction, mauling, chase, and continue to raise new issues for researchers.

For example, there is a potential for further study of the mauling scene in the context of image analysis of the horse decoration structure of both the Berel kurgan 11 and the entire burial ground.

\section{ЛІТЕРАТУРА}

Акишев, А. К. 1984. Искусство и мифбология саков. Алма-Ата: Наука.

Алтынбеков, К. 2014. Возрожденные сокровища Казахстана: опььт научной реставрации. Алматы: Остров Крым.

Алтынбеков, К., Железнякова, В. Л., Алтынбекова, Э. К. 2019. Новый образец древнего искусства из Казахского Алтая. Поволжская археология, 3 (29), с. 100-114. https://doi.org/10.24852/ ра2019.3.29.100.114.

Ардзинба, В. Г. 1982. Ритуаль и мифы Древней Анатолии. Москва: Наука.

Артамонов, М. И. 1973. Сокровища саков. Москва: Искусство.

Баркова, Л. Л., Панкова, С. В. 2005. Татуировки на мумиях из Больших Пазырыкских курганов (новые материалы). Археология, этнографбия и антропология Евразии, 2 (22), с. 48-59.

Бейсенов, А. З., Марьяшев, А. Н. 2014. Петроглиgбы раннего железного века Жетысу. Алматы: Институт археологии им. А. Х. Маргулана.

Бернштам, А. Н. 1947. Берккаринская пряжка (о скифской традиции в сарматском искусстве). Kpamкие сообшения ИИМК, 17, с. 9-11.

Бессонова, С. С., Скорый, С. А. 2020. Памяти Вячеслава Юрьевича Мурзина (1951-2019). Российская археология, 3, с. 210-211.

Богданов, Е. С. 2006. Образ хищника в пластическол искусстве кочевых народов Центральной Азии (скиббо-сибирская художественная традииия). Новосибирск: ИАЭт СО РАН.

Варенов, А. В. 2018а. Петроглифы «в стиле оленных камней» и "демонические псы» из Китая. Вестник Новосибирского государственного университета. Серия: История, филология, 17, № 10: Востоковедение, с. 9-29. DOI: 10.25205/1818-7919-2018-17-10-929.

Варенов, А. В. 2018b. О точном датировании изображений тигров в горах Хэланьшань и оленях в «стиле оленных камней». Вестник Новосибирского государственного университета. Серия: История, фрилология, 17, № 4: Востоковедение, с. 30-39. DOI: 10.25205/1818-7919-2018-17-4-30-39.

Варенов, А. В., Черемисин, Д. В. 2018. Петроглифы «в стиле оленных камней» на территории Китая. В: Тишкин, А. А. (ред.). Совреленные решения актуальных проблел евразийской археологии. 2. Барнаул: Алтайский университет, с. 250-255.

Джумабекова, Г. С., Базарбаева, Г. А. 2019. Высокохудожественная вышивка в декоре конского снаряжения из элитного погребения в Казахском Алтае. Поволжская археология, 3 (29), с. 115-127. https://doi.org/10.24852/pa2019.3.29.115.127.

Дэвлет, Е. Г. 2017. Конвергентно возникающие созвучия зооморфоным персонажам с декорированным туловищем: звериный стиль или свободная стилизация? Краткие сообщения Института археологии, 248 , с. $198-206$

Дэвлет, Е. Г., Дэвлет, М. А. 2011. Сокровища наскального искусства Северной и Центральной Азии. Москва: Институт археологии.

Килуновская, М. Е., Семенов, Вл. А. 1999. Оленные камни Тувы (Ч. 2: Сюжеты, стиль, семантика). Археологические вести, 6, с. 130-145.

Королькова, Е.Ф. 2006. Звериный стиль Евразии. Искусство плелен Нижнего Поволжья и Южного Приуралья в скифбскую эпоху (7-4 вв. до н. э.). Проблемь стиля и этнокультурной принадлеж- 
ности. Санкт-Петербург: Петербургское востоковедение.

Королькова, Е. Ф. 2015. Следы невиданных зверей (к проблеме трактовки франтастических образов). Археологический сборник Государственного Эрлитажа, 40, с. 157-188.

Кубарев, В. Д. 1987. Курганы Уландрыка. Новосибирск: Наука.

Мец, Ф. 2013. О возможных семантических параллелях «рогатым» лошадям пазырыкской культуры. Теория и практика археологических исследований, 1 (7), c. 91-102.

Миклашевич, Е. А. 2007. Исследование наскального искусства. Северной и Центральной Азии в 1995-1999 га. Кемерово: Кузбассвузиздат.

Мурзин, В. Ю. 2013. Киммерийская проблема в европейском и азиатском контекстах. В: Бейсенов, А. З. (ред.). Бегазы-дандыьбаевская культура Степной Евразии. Алматы: Институт археологии им. А. Х. Маргулана, с. 137-149.

Мурзин, В. Ю. 2019. Алексей Иванович Тереножкин - основатель киевской школы скифоведения. В: Байтанаев, Б. А., Хабдулина, М. К. (ред.). Маргулановские чтения - 2019. Нур-Султан: Евразийский национальный университет им. Л. Н. Гумилева, с. 39-46.

Мурзин, В. Ю., Шлайфер, В. Г. 2017. Амазонские мотивы по данным археологии и литературы. В: Бейсенов, А. З., Ломан, В. Г. (ред.). Археологическое наследие Центрального Казахстана: изучение и сохранение. 2. Алматы: Институт археологии им. А. Х. Маргулана, с. 230-236.

Полидович, Ю. Б. 2006. Хищник и его жертва: Выражение круговорота жизни и смерти средствами скифрского зооморфного кода. В: Евглевский, А. В. (ред.). Структурно-семиотические исследования в археологии. 3. Донецк: ДонНУ, с. 355398.

Полосьмак, Н. В. 2000. Татуировка у пазырыкцев. Археология, этнографби и антропология Евразии, 4, c. 95-102.

Полосьмак, Н. В. 2001. Всадники Укока. Новосибирск: Инфолио.

Полосьмак, Н. В., Баркова, Л. Л. 2005. Костюл и текстиль пазырыкиев Алтая (IV-III вв. до н. э.). Новосибирск: Инфолио.

Радлов, В. В. 1989. Из Сибири: страницы дневника. Москва: Наука.

Рогожинский, А. Е. 2016. Незадолго до Чжан Цяня (след движения номадов из центра Азии на Запад в последние века до нашей эры). В: Деревянко, А. П., Молодин, В. И. (ред.). Алтай в кругу евразийских древностей. Новосибирск: Институт археологии и этнографии, с. 527-550.

Руденко, С. И. 1953. Культура населения Горного Алтая в скифбское вреля. Москва: Наука.

Руденко, С. И. 1960. Культура населения Центрального Алтая в скиббккое вреля. Москва; Ленинград: АН СCCP.

Руденко, С. И. 1961. Искусство Алтая и Передней Азии (середина I тыссячелетия до н. э.). Москва: АН СCCP.

Руденко, С. И. 1962. Сибирская коллекиия Петpa I. Свод археологических источников, Д3-9. Москва; Ленинград: АН СССР.

Руденко, С. И. 1968. Древнейшие в мире художественные ковры и ткани из оледенельх курганов Горного Алтая. Москва: Искусство.

Савинов, Д. Г. 1994. Оленные кални в культуре кочевников Евразии. Санкт-Петербург: СПбГУ.
Самашев, 3. 2012. Наскальные изображения Жетылсу. Баянжурек. Астана: Институт археологии им. А. Х. Маргулана.

Самашев, 3. 2011. Berel. Алматы: Таймас.

Советова, О. С. 2017. Декорированные изображения и «алтайский» стиль в наскальном искусстве Минусинской котловины в скифскую эпоху. Kpamкие сообщения Института археологии, 247, с. 132149 .

Суразаков, А. С. 2011. О проблемах реконструкции мировоззренческой модели мира племен пазырыкской культуры. B: Molodin, V. I., Hansen, S. (eds.). Terra Scythica. Новосибирск: ИАЭт СО РАН, c. 261-268.

Черемисин, Д. В. 2008. Искусство звериного стиля в погребальных комплексах рядового населения пазырыкской культуры: селантика звериных образов в контексте погребального обряда. Новосибирск: ИАЭт СО РАН.

Юсупов, Ф. Ю. 2012. В. В. Радлов - основоположник российской тюркологической науки. Научный Tатарстан, 2, с. 196-210.

Čugunov, K. V., Parzinger, H., Nagler, A. 2010. Der skythenzeitliche Fürstenkurgan Aržan 2 in Tuva. Mainz.

\section{REFERENCES}

Akishev, A. K. 1984. Iskusstvo i mifologiia sakov. AlmaAta: Nauka.

Altynbekov, K. 2014. Vozrozhdennye sokrovishcha Kazakhstana: opyt nauchnoi restavratsii. Almaty: Ostrov Krym.

Altynbekov, K., Zhelezniakova, V. L., Altynbekova, E. K. 2019. Novyi obrazets drevnego iskusstva iz Kazakhskogo Altaia. Povolzhskaia arkheologiia, 3 (29), s. 100-114. https://doi. org/10.24852/pa2019.3.29.100.114.

Ardzinba, V. G. 1982. Ritualy i mify Drevnei Anatolii. Moskva: Nauka.

Artamonov, M. I. 1973. Sokrovishcha sakov. Moskva: Iskusstvo.

Barkova, L. L., Pankova, S. V. 2005. Tatuirovki na mumiiakh iz Bolshikh Pazyrykskikh kurganov (novye materialy). Arkheologiia, etnografiia $i$ antropologiia Evrazii, 2 (22), s. 4859 .

Beisenov, A. Z., Mariashev, A. N. 2014. Petroglify rannego zheleznogo veka Zhetysu. Almaty: Institut arkheologii im. A. Kh. Margulana.

Bernshtam, A. N. 1947. Berkkarinskaia priazhka (o skifskoi traditsii v sarmatskom iskusstve). Kratkie soobshcheniia IIMK, 17, s. 9-11.

Bessonova, S. S., Skoryi, S. A. 2020. Pamiati Viacheslava Iurevicha Murzina (1951-2019). Rossiiskaia arkheologiia, 3, s. $210-211$.

Bogdanov, E. S. 2006. Obraz khishchnika v plasticheskom iskusstve kochevykh narodov Tsentralnoi Azii (skifo-sibirskaia khudozhestvennaia traditsiia). Novosibirsk: IAEt SO RAN.

Varenov, A. V. 2018a. Petroglify «v stile olennykh kamnei» i «demonicheskie psy» iz Kitaia. Vestnik Novosibirskogo gosudarstvennogo universiteta. Seriia: Istoriia, filologiia, 17, N 10: Vostokovedenie, s. 9-29. DOI: 10.25205/1818-79192018-17-10-9-29.

Varenov, A. V. 2018b. O tochnom datirovanii izobrazhenii tigrov v gorakh Khelanshan i oleniakh v «stile olennykh kamnei». Vestnik Novosibirskogo gosudarstvennogo universiteta. Seriia: Istoriia, filologiia, 17, N 4: Vostokovedenie, s. 30-39. DOI: 10.25205/1818-7919-2018-17-4-30-39.

Varenov, A. V., Cheremisin, D. V. 2018. Petroglify «v stile olennykh kamnei» na territorii Kitaia. In: Tishkin, A. A. (ed.). Souremennye resheniia aktualnykh problem evraziiskoi arkheologii. 2. Barnaul: Altaiskii universitet, s. 250-255.

Jumabekova, G. S., Bazarbayeva, G. A. 2019. Vysokokhudozhestvennaia vyshivka $\mathrm{v}$ dekore konskogo snariazheniia iz elitnogo pogrebeniia v Kazakhskom Altae. Povolzhskaia 
arkheologiia, 3 (29), s. 115-127. https://doi.org/10.24852/ pa2019.3.29.115.127.

Devlet, E. G. 2017. Konvergentno voznikaiushchie sozvuchiia zoomorfnym personazham s dekorirovannym tulovishchem: zverinyi stil ili svobodnaia stilizatsiia? Kratkie soobshcheniia Instituta arkheologii, 248, s. 198-206.

Devlet, E. G., Devlet, M. A. 2011. Sokrovishcha naskalnogo iskusstva Severnoi i Tsentralnoi Azii. Moskva: Institut arkheologii.

Kilunovskaia, M. E., Semenov, Vl. A. 1999. Olennye kamni Tuvy (Ch. 2: Siuzhety, stil, semantika). Arkheologicheskie vesti, 6, s. 130-145.

Korolkova, E. F. 2006. Zverinyi stil Evrazii. Iskusstvo plemen Nizhnego Povolzhia i Iuzhnogo Priuralia v skifskuiu epokhu (7-4 vv. do n.e.). Problemy stilia i etnokulturnoi prinadlezhnosti. Sankt-Peterburg: Peterburgskoe vostokovedenie.

Korolkova, E. F. 2015. Sledy nevidannykh zverei (k probleme traktovki fantasticheskikh obrazov). Arkheologicheski sbornik Gosudarstvennogo Ermitazha, 40, s. 157-188.

Kubarev, V. D. 1987. Kurgany Ulandryka. Novosibirsk: Nauka.

Mets, F. 2013. O vozmozhnykh semanticheskikh paralleliakh «rogatym» loshadiam pazyrykskoi kultury. Teoriia $i$ praktika arkheologicheskikh issledovanii, 1 (7), s. 91-102.

Miklashevich, E. A. 2007. Issledovanie naskalnogo iskusstva. Severnoi i Tsentralnoi Azii v 1995-1999 gg. Kemerovo: Kuzbassvuzizdat.

Murzin, V. Iu. 2013. Kimmeriiskaia problema v evropeiskom i aziatskom kontekstakh. In: Beisenov, A. Z. (ed.) Begazy-dandybaevskaia kultura Stepnoi Evrazii. Almaty: Institut arkheologii im. A. Kh. Margulana, s. 137-149.

Murzin, V. Iu. 2019. Aleksei Ivanovich Terenozhkin — osnovatel kievskoi shkoly skifovedeniia. In: Baitanaev, B. A. Khabdulina, M. K. (ed.). Margulanovskie chteniia - 2019 Nur-Sultan: Evraziiskii natsionalnyi universitet im. L. N. Gumileva, s. 39-46.

Murzin, V. Iu., Shlaifer, V. G. 2017. Amazonskie motivy po dannym arkheologii i literatury. In: Beisenov, A. Z., Loman, V. G. (ed.). Arkheologicheskoe nasledie Tsentralnogo Kazakhs tana: izuchenie i sokhranenie. 2. Almaty: Institut arkheologii im. A. Kh. Margulana, s. 230-236.

Polidovich, Iu. B. 2006. Khishchnik i ego zhertva: Vyrazhenie krugovorota zhizni i smerti sredstvami skifskogo zoomorfnogo koda. In: Evglevskii, A. V. (ed.). Strukturno-sem ioticheskie issledovaniia $v$ arkheologii. 3. Donetsk: DonNU, s. $355-398$.

Polosmak, N. V. 2000. Tatuirovka u pazyryktsev. Arkheologiia, etnografiia $i$ antropologiia Evrazii, 4, s. 95-102.

Polosmak, N. V. 2001. Vsadniki Ukoka. Novosibirsk: Infolio.

Polosmak, N. V., Barkova, L. L. 2005. Kostium i tekstil pazyryktsev Altaia (IV-III vv. do n. e.). Novosibirsk: Infolio.

Radlov, V. V. 1989. Iz Sibiri: stranitsy dneunika. Moskva: Nauka.

Rogozhinskii, A. E. 2016. Nezadolgo do Chzhan Tsiania (sled dvizheniia nomadov iz tsentra Azii na Zapad v poslednie veka do nashei ery). In: Derevianko, A. P., Molodin, V. I. (ed.). Altai v krugu evraziiskikh drevnostei. Novosibirsk: Institut arkheologii i etnografii, s. 527-550.

Rudenko, S. I. 1953. Kultura naseleniia Gornogo Altaia v skifskoe vremia. Moskva: Nauka.

Rudenko, S. I. 1960. Kultura naseleniia Tsentralnogo Altaia v skifskoe vremia. Moskva; Leningrad: AN SSSR.

Rudenko, S. I. 1961. Iskusstvo Altaia i Perednei Azii (seredina I tysiacheletiia do n. e.). Moskva: AN SSSR.

Rudenko, S. I. 1962. Sibirskaia kollektsiia Petra I. Svod arkheologicheskikh istochnikov, D3-9. Moskva; Leningrad: AN SSSR.

Rudenko, S. I. 1968. Drevneishie v mire khudozhestvennye kovry $i$ tkani iz oledenelykh kurganov Gornogo Altaia. Moskva: Iskusstvo.

Savinov, D. G. 1994. Olennye kamni v kulture kochevnikov Evrazii. Sankt-Peterburg: SPbGU.

Samashev, Z. 2012. Naskalnye izobrazheniia Zhetysu Baianzhurek. Astana: Institut arkheologii im. A. Kh. Margulana.

Samashev, Z. 2011. Berel. Almaty: Taimas.
Sovetova, O. S. 2017. Dekorirovannye izobrazheniia i «altaiskii» stil v naskalnom iskusstve Minusinskoi kotloviny v skifskuiu epokhu. Kratkie soobshcheniia Instituta arkheologii, 247 , s. $132-149$

Surazakov, A. S. 2011. O problemakh rekonstruktsii mirovozzrencheskoi modeli mira plemen pazyrykskoi kultury. In: Molodin, V. I., Hansen, S. (eds.). Terra Scythica. Novosibirsk: IAEt SO RAN, s. 261-268.

Cheremisin, D. V. 2008. Iskusstvo zverinogo stilia v pogrebalnykh kompleksakh riadovogo naseleniia pazyrykskoi kultury: semantika zverinykh obrazov v kontekste pogrebalnogo obriada. Novosibirsk: IAEt SO RAN.

Iusupov, F. Iu. 2012. V. V. Radlov - osnovopolozhnik rossiiskoi tiurkologicheskoi nauki. Nauchnyi Tatarstan, 2, s. $196-210$

Čugunov, K. V., Parzinger, H., Nagler, A. 2010. Der skythenzeitliche Fürstenkurgan Aržan 2 in Tuva. Mainz.

\section{G. A. Bazarbayeva, G. S. Jumabekova}

\section{ON THE STUDY OF THE SCENES OF TORMENT IN THE ART OF PEOPLE OF PAZYRYK CULTURE BASED ON MATERIALS FROM KURGAN 11 OF THE BEREL GRAVEYARD IN THE KAZAKH ALTAY}

In this paper, we present the analysis of the scene from a saddle cover found in kurgan 11 of Berel $\left(4^{\text {th }}\right.$ $3^{\text {rd }}$ centuries BC). This material was first published in the Povolzhskaya Arkheologiya journal (Алтынбеков и др. 2019; Джумабекова, Базарбаева 2019). Here, we provide new data based on the analysis of the informative elements of the animal images and broaden the range of the analogies.

In the archeology of the Early Iron Age of the eastern part of Eurasia, materials from permafrost mounds are of great importance. They allow to clarify in many respects various elements of material culture of the population living in the region. The state of preservation of the contents of the tomb can be compared with ethnographic exhibits. In 1998-1999 international expedition of the Institute of Archeology. A. H. Margulan under the leadership of Z. Samashev studied the mound 11 cemetery Berel (4-3 centuries BC) in the Kazakh Altai, which preserved the lens of permafrost. The peculiarity of the excavations was that the contents of the burial chamber were removed in separate blocks for further study in the laboratory. Cabinet research was conducted in the winter of 2000 . Since then, part of the material was stored in a freezer in the research and restoration laboratory "Island of Crimea". Under the leadership of $\mathrm{K}$. Altynbekov, organic artifacts were gradually restored and preserved. A recent discovery by laboratory staff was the discovery of the remains of a saddle cover embroidered with a scene of torture by four ungulate predators. This material was first published in 2019 in the journal «Volga Archeology". This article provides materials that significantly complement the above analysis. The range of analogies has been expanded. In the interpretation of certain zoomorphic images, emphasis is placed on ornamental elements. In particular, stylized images of spiral curls found in materials from monuments of Central Asia: in the Altai, Tuva, Ordos were analyzed in detail.

The analyzed plot on the saddle cover from Berel is close, but not identical to the drawings that have survived as tattoos on the buried from Pazyryk, Ak-Alahi, Verkh-Kaldzhin. The reception in the form of blacken- 
ing of certain content elements in the transfer of images of animals, both real and fantastic, attracts attention. One of the favorite plots in the art of the Pazyriks is the scene of torment, which conveys the traditional idea of the cycle of life and death, rebirth through death.

Keywords: Kazakh Altay, Early Iron Age, art.

\author{
Г. А. Базарбаєва, Г. С. Джумабекова
}

\section{ДО ВИВЧЕННЯ СЦЕН ТЕРЗАННЯ В МИСТЕЦТВІ НОСІЇВ ПАЗИРИКСЬ- КОЇ КУЛЬТУРИ: ЗА МАТЕРІАЛАМИ БЕРЕЛСЬКОГО КУРГАНУ 11 ІУ КАЗАХСЬКОМУ АЛТАЇ}

В археології раннього залізного віку східної частини Свразії велике значення мають матеріали 3 курганів із мерзлотою. Саме вони дозволяють багато в чому прояснити різноманітні елементи матеріальної культури населення, що мешкало у регіоні. Стан збереженості вмісту внутрішньомогильної споруди можна порівняти 3 етнографічними експонатами. У 1998-1999рр. міжнародна експедиція Інституту археології ім. А. Х. Маргулана під керівництвом 3. Самашева вивчала курган 11 могильника Берел (IV-III ст. до н. е.) у Казахському Алтаї, в якому збереглася лінза мерзлоти. Особливість розкопок полягала в тому, що вміст поховальної камери виймався окремими блоками з метою подальшого вивчення у лабораторних умовах. Кабінетні дослідження проводилися взимку 2000 р. 3 того часу частина матеріалу зберігалася у морозильній установці у науково-реставраційній лабораторії «Острів Крим». Під керівництвом К. Алтинбекова артедракти з органіки поступово реставрувались та консервувалися. Нещодавнім відкриттям співробітників лабораторії стало виявлення залишків сідельного покриття 3 вишивкою, що містить сцену терзання чотирма хижаками копитної тварини. Вперше цей матеріал було опубліковано у 2019 р. у журналі «Поволзька археологія». У цій статті наводяться матеріали, що суттево доповнюють викладений раніше аналіз. Розширено коло аналогій. У трактуванні тих чи інших зооморфрних образів, зроблено акценти на орнаментальних елементах. Зокрема, детально проаналізовано стилізовані зображення спіралеподібних завитків, що зустрічаються у матеріалах з пам'ятників Центральної Азії: на Алтаї, Туві, Ордосі.

Аналізований сюжет на сідельному покритті 3 Берела близький, але не ідентичний малюнкам, що збереглися як татуювання на похованих з Пазирика, Ак-Алахі, Верх-Кальджіна. Привертає увагу прийом у вигляді зачорніння тих чи інших змістовних елементів у передачі зображень тварин, як реальних, так і фантастичних. Один з улюблених сюжетів у мистецтві пазирикців - сцена терзання, передає традиційну для досліджуваної епохи ідею круговороту життя і смерті, відродження через смерть.

Ключові слова: Казахський Алтай, ранній залізний вік, мистецтво.

Одержано 18.05.2021

БАЗАРБАСВА Галія Аппазівна, кандидат історичних наук, провідний науковий співробітник, Інститут археології ім. А. Х. Маргулана, Алмати, Казахстан.

BAZARBAYEVA Galiya A., Candidate of Historical Sciences, Chief Research Fellow, A. Kh. Margulan Institute of Archaeology, Almaty, Kazakhstan.

ORCID: 0000-0003-4755-9007, e-mail:

galiya2002@gmail.com.

ДЖУМАБЕКОВА Гульнара Саїнівна, кандидат історичних наук, провідний науковий співробітник, Інститут археології ім. А. Х. Маргулана, Алмати, Казахстан.

JUMABEKOVA Gulnara S., Candidate of Historical Sciences, Chief Research Fellow, A. Kh. Margulan Institute of Archaeology, Almaty, Kazakhstan.

ORCID: 0000-0003-2145-2615, e-mail:gdzhuma@mail.ru. 